\title{
FORMATION OF COLORISTIC CULTURE OF STUDENTS OF ART AND PEDAGOGICAL SPECIALTIES IN CLASSES OF COLORISTIC
}

The article is devoted to the necessity of the color culture formation among the students of art and pedagogical direction, namely: of color visual perception aspects, obtaining knowledge of color and historical stages of development of color systems, the formation of holistic ideas about color and types of color harmonies, the ability to analyze works of art and engage in common cultural values. In a study updated questions of finding and implementing new learning models that can contribute to the integrity of the educational process in chromatics, identify various types of ties, and bringing them into a single picture aimed at the development of creativity, independence, mobility, and competitiveness of future specialists. The study of color is considered as an important component of the entire system of teachers of painting training. Attention is paid to the expanded development of various artistic materials and techniques, the effectiveness of the educational potential of art, in order to form a spiritual culture, the personality of future teachers of fine arts, understanding, vision, and application of color.

In the article on the basis of the scientific and pedagogical literature analysis on the researched problem and author's concepts of perception and use of color, necessity of development at students of system coloristic thinking is proved, the expediency of development and application of methods of teaching color science which would promote the development of a sense of color and figurative color thinking is substantiated. In order to form the necessary artistic and pedagogical competencies provided by the teaching program, the systematic approach in the theory and practice of teaching in color studies and the interaction of all of color education components are necessary. Attention is paid to the proportional combination of theoretical and practical tasks in coloristic on the basis of block-thematic connections, the implementation of which will provide knowledge of color, the ability to analyze works of art, and the acquisition of practical skills with color required for educational and creative work. The article presents the basic principles of teaching color culture, mastering which will allow students to use color professionally as a means of artistic expression, which is necessary for further artistic and pedagogical activities.

Key words: coloristic culture, pedagogical activity, teaching methods, educational process, coloristic science, system approach.

Formulation of the problem. In accordance with the modern requirements of aesthetic development of schoolchildren, the problem of the formation of artistic and pedagogical competencies of the future teachers of painting becomes crucial. The development of students' systems thinking, the ability to consider problems comprehensively has become a conscious need for the professional education of future professionals. In modern conditions, the most important problem is the training of teachers in painting, which carry out aesthetic education and art education of the younger generation. A highly qualified specialist which teaches children to understand art must have a set of general and special knowledge and skills, the most important of which is knowledge of color and the ability to work with color. Coloristic preparation of art and pedagogical specialties students does not sufficiently ensure the achievement of the set tasks.

The traditional approach to the teaching of colorism does not contribute to the formation of students' holistic ideas about color as a means of artistic expression. At the same time, the problem of system-forming connections in the teaching of professional disciplines remains unsolved. Based on this, it is necessary to implement the principles of a systematic approach in teaching students the basics of colorism.

Analysis of research and publications. The problem of training a teacher of painting for the system of general and additional education has been the subject of research by a wide range of scientists. Such sciences like an honorary worker of higher professional education, painter Zaitsev O. S., author of a number of textbooks on color science. The artist-teacher, doctor of pedagogical sciences Bida G. D., Doctor of Pedagogical Sciences, Professor Bogolyubov L. N. dedicated their work to the formation of the coloristic culture of students.

The pedagogical aspect of this problem was considered in the writings of Zinchenko V. P. He emphasizes the feasibility of implementing a systematic approach in the training of future professionals, the importance of the interaction 
of components of the content of education, the implementation of pedagogical principles of teaching.

Integration processes in the field of modern art education involve the systematic interaction of special disciplines. The works of such philosophers as Blauberg I. V, Sadovsky W. M., and Yudin A. G. are very interesting in the field of systematization of coloristic preparation, they direct the researcher to reveal the integrity of the educational process, identify various types of communication and bring them into a single picture. From the standpoint of this problem, the author's concepts of perception and use of color, developed by Itten I., Malevich K. S., and other painters who directly influenced the development of applied color are of undoubted interest.

In our time there is a contradiction between the necessity to solve color problems in creative and pedagogical activities and the lack of scientifically sound methods of forming understanding, vision, and application of color in future teachers of painting in high school. This contradiction has necessitated the development of modern didactics of color, identified general issues, and relevance of the research topic.

Goal forming. The purpose of this article is to study the problem of developing the content and methods of improving the coloristic training of future teachers of painting, the theoretical justification of the principles of a systematic approach to teaching coloristic science to students of art, and pedagogical specialties.

Presenting of the main material. Training of the teachers of painting in the higher school system is a complex process that requires constant improvement and deepening of the theoretical basis of teaching, searches, and implementation of new methods and techniques in all disciplines of the art cycle. To date, such programs have been developed in the fine arts, work with which requires improving teacher training in general, and in the field of color - in particular. In this regard, the requirements for the professional level of professionals who are called to teach fine arts in schools, lyceums, colleges, and other educational institutions are increasing.

The main purpose of art education of young people in the formation of the spiritual culture of the individual, his involvement in cultural values. In this process, much depends on the spiritual and artistic culture of the teacher of painting. Carrying out artistic and aesthetic training of children, the teacher must form their artistic perception, through practical creative activities to improve visual skills and on this basis to develop creative abilities.

The studying of color at art and pedagogical faculties is traditionally considered an important component of the whole system of training teacher of painting.

The most important task of the general system of teaching students of art and pedagogical specialties is the development of students' perception of color, the ability to reproduce it in educational and creative work, as improving color training, including understanding, vision, and application of color in creative and pedagogical activities helps to increase the level of professionalism of future professionals.

The studying of color harmony provides training for qualified teachers of painting for high school, able to teach fine arts at a high theoretical level. The development of color vision in students involves mastering the techniques of professional perception, "eye staging" [1, p. 259]. Data from the psychophysiology of visual perception indicate that the understanding and vision of color are inextricably linked and formed in the process of human activity.

In the structure of sensory - figurative thinking and on its basis the aesthetic relation to reality is formed, and the development of a feeling of color plays an important role in this process [2, p. 90].

Hegel G. V. emphasized the importance of forming the correct color vision in the visual process: "The sense of color should be an artistic property, a kind of way of seeing and understanding existing color tones, and should be an essential aspect of reproducing the ability of imagination and ingenuity" [3, p. 239].

That is why it is so important to unite in a holistic system the theory and methods of mastering the understanding, vision, and application of color in creative and pedagogical activities and the inclusion of these components in the practice of the future teacher of painting. The development of color vision and the transfer of theoretical knowledge about color are especially important at the initial stage of learning when the foundation is laid for further growth of professional skills and knowledge of students. This period especially requires the scientific validity of teaching the basic issues of theory and a strictly verified sequence of mastering the methods and techniques of color vision and purposeful use of color.

Coloristic training of the future teacher of painting should be based on a system of special knowledge of color, which include: knowledge of the laws of color composition, visual perception of color; historical aspect of the problem of applying color in art; mastering theoretical concepts in the field of color; studying of formative and psychophysiological properties of color, its expressive features, and patterns, methods, forms, techniques and means of figurative expression; experience of creative activity, which involves the implementation of the color organization of the plane through the creative interpretation of the color scheme of nature; imaginary processing of the received visual information about color and its translation into the language of decorative and applied art; professional and evaluative knowledge and ability to make a color analysis of a work of art; mastery of skills and techniques of color combinations. 
In the modern system of art education, teaching the basics of color science is traditionally carried out in the framework of painting classes. Based on the analysis of scientific and pedagogical literature on the research problem and experience with students of art and pedagogical specialties, we can assume that the introduction of a systematic approach to teaching color will contribute to the formation of artistic and pedagogical competence of future teachers of painting, as "Color", "Painting", "Composition", "Art and Applied Graphics" will be based on the unity of the content of block-thematic connections.

In order to form the basis of students' color competence, it is necessary not only to focus students' attention on issues of coloristic science, as one of the key disciplines to achieve the goals of art and pedagogical education but also to promote

- the development of creative abilities of students;

- the studying of the symbolic component of color;

- the studying of color systems history and color harmony;

- the formation of a clear understanding of the difference between the perception of color by an adult and a child;

- the acquisition of skills training and analysis of their creative works and paintings of famous artists.

To achieve these aims, the most productive will be learning the basics of color by performing specially designed tasks in color science based on the circle-harmonizer, which will differ from the known, presented in the works of I. Itten, color circle $[4$, p. 15]. In the circle-harmonizer, along with the main, there are two more color circles (outer and inner). The outer circle is a chromatic color with the addition of achromatic black, and the inner - with the addition of achromatic white (pastel tones). The above mentioned allows students to expand their understanding of the ranges of color tone, will allow comparison, and expand the scope of its gradations.

The basic principles of coloristic learning culture include:

- obligatory initial mastering of general theoretical knowledge about color (physical, psychological, properties of color) in close connection with practical exercises on coloristic;

- practical classes in painting, aimed at reflecting the general coloring of objects, mastering the laws of harmonization of color comparisons (relationships);

- study of author's color systems, carried out on the basis of the analysis of various harmonious color combinations (dyads, triads, tetradiads, etc.);

- creative development of students, acquaintance with the principles of the Luscher color test [5].

Only on the basis of knowledge of the objective world laws, a true transfer of the surrounding reality coloristic state is possible. Their absence complicates the creative process of the artist, leads to unjustified conventionality of expressive means [6, p. 98].

Art is a set of practical skills, theoretical knowledge, figurative spatial thinking, sensoryemotional perception of the world [7, p. 121], and for its formation, the process of teaching fine arts should include methods that would promote the development of figurative thinking, which includes a sense of color. Confirming this theory, Professor Zinchenko V. P. points out that "methods of activating figurative thinking are at the same time methods of activating creative search" [8, p. 58]. Aesthetic education is a mandatory aspect of activating figurative thinking, and aesthetic evaluation is a necessary element of an artistic color image creation in each student.

In turn, according to Deineka O. O., the holistic perception of the color image should serve not only as a starting point for its detailed consideration but also a constant background on which each part is singled out and studied separately [9, c. 128]. In the learning process, it is important to focus on those fundamental sections of color science and painting theory that allow students to complete the tasks.

Conclusions. The modern system of teachertraining has to take into account the changing socio-cultural situation and focus all education on the formation of artistic and pedagogical abilities of students to professional activities.

The inconsistency of educational-cognitive processes and creative activity, the lack of general artistic and special disciplines interconnection leads to the disunity of students' comprehension of the color science basics.

The tendency to the interaction with different sciences, the integration of the educational process stimulates the creation of new models of learning aimed at developing creative initiative, independence, competitiveness, and mobility of future professionals. The developing nature of the educational process justifies the feasibility of introducing a systematic approach to the training of future professionals, the importance of the interaction of components of the content of education, and the need for effective use of the educational potential of art. Mastering one of the most important means of artistic expression color is a priority of professional education of future artists-teachers. Color literacy training is a multistage process, which is one of the effective means of aesthetic education.

Coloristic training of art and pedagogical specialties students requires a systematic approach to coloristic science learning, improving and deepening the theoretical basis, search and implementation of new methods and techniques in the educational process. The course of coloristic science should systematize knowledge of special disciplines on the basis of blockthematic connections. Training programs have to 
provide an in-depth study of the historical aspect of the coloristic systems development, psychophysiological properties of color, the laws of visual perception of color, the study of its symbolic component.

The course of coloristic science for art and pedagogical specialties should include a block of practical tasks in color, aimed at mastering professional skills in the field of color organization of the plane. Systematization of coloristic training of students, based on the development of theoretical knowledge and interaction of different types of artistic activities, can become the basis of a modern model of teaching coloristic science to students of art and pedagogical specialties and contribute to the achievement of their tasks.

\section{References:}

1. Чистяков П.П. Письма, записные книжки, воспоминания. Москва : Искусство, 1953. 594 с.

2. Коробко Ю.В. Теоретическое и методическое обоснование живописного понимания и видения цвета : дисс. ... кандидата пед. наук : 13.00.02. Краснодар, 1997. 216 с.
3. Гегель Г.В. Энциклопедия философрских наук. Москва : Мысль, 1975. 452 с.

4. Иттен И. Искусство цвета. Москва : Д. Аронов, $2001.96 \mathrm{c}$.

5. Люшер М. Цветовой тест Люшера. Москва : ЭКСМО-Пресс, 2005. 192 с.

6. Беда Г.В. Основы изобразительной грамоты: Рисунок. Живопись. Композиция. Москва : Просвещение, 1981. 239 с.

7. Зайцев А.С. Наука о цвете и живопись. Москва : АСТ Астрель, 2014. 158 с.

8. Зинченко В.П. Психологические основы педагогики : учеб. пособ. Москва : Гардарики, 2002. $431 \mathrm{c}$.

9. Дейнека А.А. Учитесь рисовать. Москва : Академия художеств, 1961. 224 с.

10.Наливина Т.И. Практическое цветоведение. Москва : Мысль, 2003. 96 с.

11.Блауберг И.В., Садовский В.Н., Юдин Э.Г. Системный подход: предпосылки, проблемы, трудности. Москва : Знание, 1999. 48 с.

12.Анцифирова Л.В. Физика цвета и психология восприятия. Новосибирск : НГТУ, 2011. 78 с.

Капран О. В. Формування колористичної культури студентів художньо-педагогічних спеціальностей на заняттях 3 кольорознавства

Статтю присвячено питанням необхідності формування колористичної культури у студентів художньо-педагогічного спрямування, а саме: аспектам зорового сприйняття кольору, отриманню знань з колористиці й історичних етапів розвитку колористичних систем, формуванню цілісних уявлень про колір та види колірних гармоній, здатності аналізувати твори мистецтва та залученню до загальних культурних цінностей. У дослідженні актуалізуються питання пошуку і впровадження нових моделей навчання, здатних сприяти цілісності освітнього процесу в галузі кольорознавства, виявленню різноманітних типів зв'язків і зведення їх в єдину картину, націлених на розвиток творчої ініціативи, самостійності, конкурентоспроможності та мобільності майбутніх фрахівців.

Вивчення кольору розглядається як важлива складова частина всієї системи підготовки художника-педагога. Приділяється увага розширеному освоєнню різних художніх матеріалів і технік, ефеективності використання виховного потенціалу мистецтва з метою формування духовної культури, особистості майбутніх учителів образотворчого мистецтва, розуміння, бачення і застосування кольору.

У статті на основі аналізу науково-педагогічної літератури з досліджуваної проблеми та авторських концепцій сприйняття і використання кольору доведено необхідність розвитку в студентів системного колористичного мислення, обгрунтовано доцільність розроблення і застосування методики викладання кольорознавства, яка би сприяла розвитку відчуття кольору та образного колірного мислення. 3 метою фоормування необхідних художньо-педагогічних компетентностей, передбачених навчальною програмою, обгрунтовано необхідність застосування системного підходу в теорії та практиці навчання на заняттях з кольорознавства, важливість взаємодії всіх компонентів колористичної освіти. Увага приділяється пропориійному поєднанню теоретичних і практичних завдань з кольорознавства на основі блочно-тематичних зв'язків, виконання яких забезпечить отримання як знань по колористиці, здатність аналізувати твори мистецтва, так і придбання практичних навичок роботи з кольором, потрібних під час створення навчальних і творчих робіт. У статті наведені основні принципи навчання колористичній культурі, опанування якими дозволить студентам профресійно користуватися кольором як засобом художнього вираження, що необхідно для подальшої художньо-педагогічної діяльності.

Ключові слова: колористична культура, педагогічна діяльність, методи навчання, освітній процес, кольорознавство, системний підхід. 